\title{
Macroeconomic Shocks and Banking Supervision ${ }^{1}$
}

\author{
Jean-Charles ROCHET ${ }^{2}$
}

March 2004

\begin{abstract}
We build a simple model of banking in the presence of macroeconomic shocks where the comparative roles of private and public monitors can be analyzed. This model provides endogenous justifications for prudential regulation (capital requirements) and emergency liquidity assistance by the Central Bank (lender of last resort). We show that market discipline can be helpful, but does not solve the fundamental problem of regulatory forbearance. We propose some directions of reform of the regulatory system that could improve the management of banking crises.
\end{abstract}

J.E.L. Classification Codes: E5, G21

Key words : Macro-prudential supervision, capital requirements, lender of last resort.

\footnotetext{
${ }^{1}$ Acknowledgment: This paper was prepared for the SET International Conference on "Organisation Design, Corporate Governance and Regulation" held in Milano, 13-14 November 2003. An early version was presented for the Gaston Eyskens Lectures 2000. I thank the Katholieke Universiteit Leuven for financial support and the audience of the Lectures and of the SET Conference for stimulating comments. I also benefitted from the comments of Tito Cordella, Haizhou Huang, Olivier Jeanne and seminar participants at the IMF.

${ }^{2}$ GREMAQ and IDEI-R, Université des Sciences Sociales, 21 allée de Brienne, 31000 Toulouse, France.

Tel. 33(0)5.61.12.86.41 - Fax 33(0)5.61.12.86.37 - Email: rochet@cict.fr.
} 


\section{1- INTRODUCTION}

The spectacular banking crises that many countries have experienced in the last twenty years (see for example Lindgren et al., 1996 for a list) have led several bankers, politicians and economists to advocate in favor of increasing the pressure of market discipline on banks, as a complement to prudential regulation and supervision. They argue that the increased complexity of financial markets and banking activities have made traditional centralized regulation insufficient, either because it is too crude (like the Basel accords of 1988) or too complex to be applicable (like the standardized approach that was proposed by the Basel committee to account for market risks in the first revision of the Basel accords). Moreover the increase in competition, both among banks and with non-banks, has made it impossible to maintain the status-quo, where banks were protected from competition by regulators, in exchange for accepting some restrictions on their activities.

Subordinated debt (SD) proposals (e.g., Wall, 1989; Gorton and Santomero, 1990; Evanoff, 1993; Calomiris, 1998, 1999), whereby commercial banks would be required to issue a minimum amount of subordinated debt on a regular basis, have been put forward in order to implement such an increase in the pressure of market discipline. Indeed if the bank is forced by regulation to issue SD on a regular basis, it will have incentives not to take too much risk since the cost of issuing new SD increases when the risk profile of the bank increases (direct market discipline). Similarly if the capital adequacy requirement of the bank depends negatively on the secondary market price of its $\mathrm{SD}$, the bank will have incentives to limit its risk of failure since that the price of SD on secondary markets decreases when the risk of failure of the bank increases (indirect market discipline). 
However, empirical evidence on the real effectiveness of market discipline is mixed. ${ }^{1}$ In particular, Flannery and Sorescu (1996) argue that market discipline can only work if absence of government intervention is anticipated. Moreover the relative performances of market discipline VS supervision have not been analyzed in the context of macroeconomic shocks, the main trigger of banking crises. This is the line of research that we examine here. We adapt the model of Holmström and Tirole $(1997,1998)$ to study in the simplest possible fashion the comparative roles of market discipline and centralized supervision in a context where banks can be hit by macroeconomic shocks.

Our results suggest that the main cause behind the poor management of banking crises may not be the "safety net" per se as argued by many economists, but instead the lack of commitment power of banking authorities, who are typically subject to political pressure. We show that the use of private monitors (market discipline) is a very imperfect mean of solving this commitment problem. Instead, we argue in favor of establishing independent and accountable banking supervisors, like has been done for monetary authorities. We also suggest a differential regulatory treatment of banks according to their exposure to macroeconomic shocks. In particular, we argue that banks with a large exposure to macroshocks should be denied the access to emergency liquidity assistance by the central bank. By contrast, banks with a low exposure to macro-shocks should have access to the lender of last resort but would face a capital ratio and a deposit insurance premium that increase with this exposure to macro-shocks.

The plan of the rest of this article is the following:

- In Section 2, we briefly survey the academic literature on bank supervision and market discipline.

\footnotetext{
${ }^{1}$ See for example Flannery (1998), Sironi (2000) and the references therein.
} 
- In Section 3, we develop a simple model of moral hazard in banking (closely inspired of Holmström and Tirole 1997) that justifies the need for prudential regulation and/or market discipline.

- In Section 4 we extend this model by introducing macroeconomic shocks and determine the optimal closure rule for banks in a situation of crisis. We also identify the source of regulatory forbearance: the lack of commitment power by political authoritites.

- In Section 5 we introduce market discipline and show that it does not solve the problem of regulatory forbearance.

- Finally, Section 6 concludes by offering policy recommendations for reforming banking supervisory systems.

\section{2- A BRIEF SURVEY OF THE LITERATURE}

Following the implementation of the first Basel Accord ${ }^{2}$ (1988, Basel Committee on Banking Supervision), academic research has spend a lot of effort in trying to assess the consequences of minimum capital standards on banks' behavior. For example, Furlong and Keeley (1989) show that value-maximizing banks tend to reduce risk-taking after a capital requirement is imposed. Using a mean-variance framework, Kim and Santomero (1988) and Rochet (1992) show that improperly chosen risk weights induce banks to select inefficient portfolios, and to undertake regulatory arbitrage activities which might paradoxically result in increased risk taking. These activities are analyzed in detail in Jones (2000).

Given these difficulties, banking regulators have tried to incorporate additional capital requirements for taking into account, for example, interest rate risk and market risk. After

\footnotetext{
${ }^{2}$ Initially designed for internationally active banks of G-10 countries, it has been later extended to a great number of countries.
} 
trying to impose a complex and ad-hoc "standard approach", they have been forced to accept the idea that commercial banks use their own internal models [Value at Risk methods] that are validated ex post by regulators. Besanko and Kanatas (1993) and Boot and Greenbaum (1993) argue that increased capital requirements may reduce the monitoring incentives of banks and as a result decrease the quality of banks' assets. Blum and Hellwig (1995) study the macroeconomic implications of capital requirements and show that they tend to amplify business cycle fluctuations. Blum (1999) argues that when dynamic effects are properly taken into account, increasing capital requirements also increases the value of future profits for banks and thus may paradoxically induce banks to more risk taking .

Dewatripont and Tirole (1994) provide an incomplete contract approach to capital regulations. In their view, banking authorities are there to represent the interest of small, dispersed depositors who don't have the competence nor the incentives to monitor banks' assets. In their theory, capital requirements are an instrument for allocating control rights to the deposit insurance fund (or to the regulator) when things go badly. They criticize the Basel accord for being too lenient during booms and too tough during recessions, since outside intervention only depends on the absolute performance of the bank (whereas they argue that it should only depend on its relative performance).

Hellman, Murdock and Stiglitz (2000) argue in favor of reintroducing interest rate ceilings on deposits as a complementary instrument to capital requirements for mitigating moral hazard. By introducing these ceilings, the regulator increases the franchise value of the banks (even if there are not currently binding) which relaxes the moral hazard constraint. Similar ideas are put forward in Caminal and Matutes (2002). Furfine (2000) calibrates a dynamic model of bank behavior with moral hazard and argues that capital regulation strongly influences bank decision making. Milne and Whalley (1998) in a similar framework, argue 
that audit frequency by the supervisor can be a much more efficient tool for restraining moral hazard than capital requirements.

Many authors have advocated in favor of introducing market discipline (e.g. Calomiris 1998, 1999) but empirical evidence is ambiguous (Flannery-Sorescu, 1996), (GortonSantomero, 1990). Several studies (Hannan and Hanweck, 1988; Ellis and Flannery, 1992; Cook and Spellman, 1996) conclude that uninsured (and paradoxically even insured) deposits yields contain risk premia. The behavior of depositors during banking crises has also been studied. For example, Martinez Peria and Schmuckler (2001) study the banking crises in Argentina, Chile and Mexico in 1994-95 and show that depositors are able to distinguish the "bad" banks and that they "punish" them by withdrawing their deposits. Park and Peristiani (1998) also show that risky banks typically attract less depositors. However, d'Amato et al. (1998) find that macro shocks and contagion effects are also important in the explanation of banking crises. The impact of deposit insurance is less clear: Demirguc-Kunt and Detragiache (1997) find that explicit deposit insurance schemes tend to favor the occurrence of systemic risk. Cull (1998) finds that, since 1980, the countries that have established explicit deposit insurance schemes have had a lower increase in their financial depth ${ }^{3}$ that the countries who did not. The main explanation they offer is that these deposit insurance schemes benefit from an implicit guarantee by the government, and insurance premiums do not reflect risks accurately. As a result, banks have a tendency to take very risky positions. However, when deposit insurance systems are adopted in a credible fashion (for example after a crisis or during a period of stability) they tend to have the opposite effects of increasing financial depth.

\footnotetext{
${ }^{3}$ Financial depth is measured by the ratio $\frac{M 2}{G D P}$.
} 


\section{3- A SIMPLE MODEL OF PRUDENTIAL REGULATION WITHOUT MACROECONOMIC SHOCKS}

In this section we introduce the benchmark model of banking regulation in the absence of macroeconomic shocks. We consider a static model with 2 dates $(t=0,1)$ inspired of Holmström and Tirole ${ }^{4}$ (1997), where banks are modeled as delegated monitors à la Diamond (1984). Banks collect a volume $D$ of deposits from the public and invest them, together with their own funds $E$, in loans to private borrowers. The volume of loans granted by the bank is denoted by $L$. Since we focus on the role of banks as monitors of private borrowers, we take small depositors out of the picture by assuming that they are perfectly insured by a Deposit Insurance Fund (DIF). We also neglect conflicts of interest inside the bank, i.e. between managers and shareholders. Thus, in the first version of the model there are only two protagonists: ${ }^{5}$ the "banker" (who represents the collective interests of the bank's managers and shareholders) and the DIF (which subrogates the collective interests of retail depositors). The budget constraint of the bank at date 0 is thus

$$
D+E=L+P
$$

where $P$ is the deposit insurance premium charged by the DIF. The lending technology has constant returns to scale. ${ }^{6}$ This return is binomial: $R$ (per unit) in case of success and zero in case of failure. All agents are risk neutral and don't discount future payments (alternatively, the interest rate is normalized to zero). Banking supervision is modeled as a contract between

\footnotetext{
${ }^{4}$ Homström and Tirole study the financing needs of nonfinancial firms. We adapt their model to study the financing needs of banks.

${ }^{5}$ We later introduce sophisticated investors, who play the part of private monitors.

${ }^{6}$ Empirical evidence on the nature of returns to scale in the banking sector is mixed. Moreover, capital requirements are (for a given assets structure) roughly proportional to the size (assets volume) of the bank. Thus, assuming constant returns seems to be a reasonable approximation of reality.
} 
the banker and the DIF. ${ }^{7}$ This contract stipulates the volume of loans $L$ and the volume $D$ of deposits that the bank can collect, the level of equity $E$ being taken as given. The specificities of banking are thus captured by three assumptions:

- First we assume that $L>D$, which implies that some fraction of bank loans are financed by deposits.

- Second, we assume that the quality of loans is affected by an unobservable decision of the banker. He can either monitor the loans, in which case they have a "high" probability of repayment $p$, or "shirk", in which case the loans have a probability of repayment of only $p-\Delta p$. Shirking provides the banker with a private benefit with monetary equivalent $B$ (per unit of investment).

- The social value of the bank exceeds the present value of its investments: we assume that, from the point of view of the economy ${ }^{8}$ as a whole, the bank has an additional continuation value of $v \geq 0$ per unit of assets, which corresponds for example to public good aspects of the bank's activity such as the bank's role in the payments system ${ }^{9}$ (Solow 1982).

The time line of the model is summarized in Figure 1.

[FIGURE 1 ABOUT HERE]

At this stage, we need two assumptions on the parameters of our model:

Assumption 1: $(p-\Delta p) R+B+v<1<p R+v$

\footnotetext{
${ }^{7}$ In fact, the contract is signed between the banker and the regulator, who is supposed to represent the interests of the DIF.

${ }^{8}$ There may also be a private continuation value, associated to the banker's non transferable knowledge of borrowers (relationship banking as in Sharpe 1990, or Degryse and Van Cayseele, 2000). We don't discuss this aspect.

${ }^{9}$ This feature is not crucial: our results also hold when $v=0$. However in the next section it allows us to discuss the basic trade-off confronted by banking authorities during crises: rescuing insolvent banks and losing credibility or closing them and creating social disruption.
} 
Assumption 1 means that loans have a positive social value only when they are monitored. This assumption implies in particular that $R>\frac{B}{\Delta p}$.

Assumption 2: $p\left(R-\frac{B}{\Delta p}\right)<1$

As explained below, Assumption 2 implies that banks need capital. If it was not satisfied, banks could be $100 \%$ externally financed.

The optimal contract $\left(L^{*}, D^{*}\right)$ maximizes expected social surplus under two constraints: The DIF has to break even and the banker must be given incentives to monitor the loans. Denoting by $P$ the premium paid by the bank to the DIF, and using the budget constraint of the bank at date 0 , we see that the DIF breaks even if and only if:

$$
P=D+E-L \geq(1-p) D
$$

or:

$$
L \leq p D+E
$$

Similarly, the incentive compatibility constraint is:

$$
p(R L-D) \geq(p-\Delta p)(R L-D)+B L,
$$

which can be rewritten as:

$$
D \leq\left(R-\frac{B}{\Delta p}\right) L .
$$

The optimal contract $(L, D)$ is thus a solution of:

$$
\left\{\begin{array}{l}
\max L[p R+v-1] \\
L \leq p D+E \\
D \leq\left(R-\frac{B}{\Delta p}\right) L .
\end{array}\right.
$$


Proposition 1: In the absence of macroeconomic shocks, the optimal organization of the banking sector can be implemented by a combination of two instruments:

- A deposit insurance system financed by (fair) risk-based premiums:

$$
P=(1-p) D,
$$

- A capital adequacy requirement limiting banks' lending to a certain multiple of their equity:

$$
L \leq \frac{E}{k}, \text { where } k=p \frac{B}{\Delta p}-(p R-1)>0 .
$$

Proof: The optimal organization of the banking sector is obtained by solving the above program. The solution is obtained by saturating the two constraints. In particular:

$$
D^{*}=\left(R-\frac{B}{\Delta p}\right) L^{*}
$$

Plugging this into the other constraint, we obtain:

$$
L^{*}\left[1-p\left(R-\frac{B}{\Delta p}\right)\right]=E .
$$

These two conditions characterize the optimal contract $\left(D^{*}, L^{*}\right)$.

We now show that this contract can be implemented by actuarial deposit insurance premiums and a capital requirement $E / L \geq k$. Indeed shareholders' value equals

$$
S=p[R L-D]
$$

where $L=D+E-P=p D+E$ (since deposit insurance is actuarially priced).

Therefore shareholders' value can also be written as:

$$
S=(p R-1) L+E,
$$


which is increasing in $L$. Thus if the bank is subject to a capital requirement $L \leq \frac{E}{k}$, shareholders will select the maximum possible volume of loans $L=\frac{E}{k}$. By choosing in turn the appropriate level for the capital ratio, i.e.

$$
k=p \frac{B}{\Delta p}-(p R-1)
$$

the bank regulator will implement the optimal allocation $\left(D^{*}, L^{*}\right)$.

Notice that this optimal allocation can also be implemented by a private arrangement between the DIF and the banker: the DIF offers a deposit insurance contract with a fair premium $P$ and stipulates that the bank's assets $L$ should not exceed $\frac{E}{k}$. The difference between private and public arrangements only appears if macro shocks are introduced. This is what we do in Section 4.

\section{4- HOW TO DEAL WITH MACROECONOMIC SHOCKS?}

Protection of depositors is not the only preoccupation of bank supervisors: they also care about what may lead to the instability of the financial system as a whole (systemic risk). The theoretical literature has insisted a lot on a first cause of instability, namely bank runs, provoked by a sudden loss of confidence of depositors in the banks' safety. These bank runs were for example very common in the US prior to the creation of the Fed. However, since the implementation of deposit insurance systems in most countries, such bank runs have become much less frequent, and banking authorities are now more concerned about systemic risk. One strand of the literature (e.g. Rochet and Tirole (1996), or Freixas et al. (2000)) has examined the possible mechanisms of contagion, i.e. propagation of one bank failure to other banks. We focus here on another source of systemic risk, namely systematic risk, generated by a common exposure of banks to macroeconomic shocks, like recessions, asset markets crashes 
and the like. We introduce these macro shocks by assuming, as in Holmström and Tirole ${ }^{10}$ (1998), that at an interim date $(t=1 / 2)$, each bank ${ }^{11}$ suffers with some probability $q$ from a liquidity shock: continuation can only occur if an additional amount of cash $\rho L$ is injected in the bank. We interpret this shock as resulting from a non diversifiable event, like a recession: the projects financed by the bank need a further injection of cash, otherwise they lose all value. We assume that the probability $q$ is sufficiently small for bank lending to remain profitable even if the risk of recession is taken into account. Specifically:

Assumption 3: $(1-q) p R>1$.

Notice that all banks are hit simultaneously but $\rho$ differs across banks. This parameter $\rho$ is known ex ante by the supervisor: it measures the bank's exposure to macro shocks.

The new time line is indicated by the Figure 2 .

\section{[FIGURE 2 ABOUT HERE]}

Confronted with the possibility of such macro-shocks, the regulators have now to consider the situation of the banking system as a whole. We assume that there is a continuum of banks, which for simplicity only differ through their exposure ${ }^{12} \rho$ to macro-shocks. $\rho$ is distributed according to a continuous distribution with continuous distribution function $F$. $F(\hat{\rho})$ can thus be interpreted as the proportion of banks such that $\rho \leq \hat{\rho}$.

Since $\rho$, the macro-exposure of each bank, is known ex-ante by the supervisors, the optimal regulation contract can be conditioned on it. Moreover the supervisors may decide to

\footnotetext{
${ }^{10}$ In Holmström and Tirole (1998) the cause of the liquidity shock can be microeconomic (i.e. diversifiable) or macroeconomic. We focus here on the second case.

${ }^{11}$ Holmström and Tirole (1998) do not consider banks but instead non-financial firms. Moreover they take $\rho$ to be a random variable, but assume that it is identically distributed across firms. We assume instead that $\rho$ is deterministic, but varies across banks.

12 This exposure results in fact from policy decisions by banks, and therefore should be endogenized. We leave this for further research. In this paper, the distribution of $\rho$ is taken as exogenous.
} 
close a bank at $t=1 / 2$ in case of a recession, again conditionally on $\rho$. We denote by $x(\rho) \in[0,1]$ the probability that the bank is allowed to continue in case of recession. If a bank is closed, its assets are liquidated ${ }^{13}$ and its depositors are compensated by the DIF. A regulation contract is described by a continuation probability $x(\rho)$, a volume of loans $L(\rho)$ and a volume of deposits $D(\rho)$. For the moment, we adopt a normative view point and solve for the (ex ante) optimal contract without specifying the way in which it is implemented (this is done in the next section).

Since moral hazard takes place after the liquidity shock, it is easy to see that the optimal volume of deposits still corresponds to the maximal payment that can be obtained from bankers while preserving incentive compatibility, namely:

$$
D(\rho)=\left(R-\frac{B}{\Delta p}\right) L(\rho)
$$

We rule out cross subsidies between banks or between the banking sector and the government. Thus, taking into account the expected cost of liquidity injections, the budget constraint of the bank at date 0 can then be written:

$$
L(\rho)\left[1-\{1-q+q x(\rho)\} p\left(R-\frac{B}{\Delta p}\right)+q \rho x(\rho)\right]=E .
$$

This budget constraint takes into account the unconditional probability of continuation of the bank at $t=1 / 2$ (that is, $1-q+q x(\rho))$ and the liquidity injection needed in case of a recession (that is, $\rho x(\rho)$ ).

Social surplus $W$ is the sum of two terms:

- the expected net surplus generated by bank lending,

\footnotetext{
${ }^{13}$ For simplicity, we assume that the liquidation value of the bank's asset at $t=1 / 2$ is zero.
} 
- the social value of the banking system as a whole, captured by a function ${ }^{14}$ $V$ of the total assets $\bar{L}$ of the banks at the interim date $t=1 / 2$.

Therefore:

$$
W=\int_{0}^{+\infty}\{(1-q) p R+q x(\rho)(p R-\rho)-1\} L(\rho) d F+V(\bar{L})
$$

where

$$
\bar{L}=\int_{0}^{+\infty} L(\rho)\{1-q+q x(\rho)\} d F
$$

The optimal regulatory contract is obtained by choosing $x(\cdot)$ and $L(\cdot)$ that maximize $W$ under the budget constraint (4) of each bank.

Proposition 2: In the presence of macroeconomic shocks, the optimal regulatory contract is characterized by a separation of banks into two categories:

- The banks such that $\rho \leq \rho^{*}=\frac{1}{1-q}$ (small exposure to macro shocks) are rescued in case of a crisis, but they are subject to a higher capital ratio (than in the absence of macro shocks). This capital ratio increases with their exposure $\rho$ to macro-shocks:

$$
k_{1}(\rho)=\frac{E}{L(\rho)}=1-p\left(R-\frac{B}{\Delta p}\right)+q \rho
$$

- The banks such that $\rho>\rho^{*}$ (large exposure to macro shocks) are closed in case of a crisis and are subject to a flat capital ratio:

$$
k_{0}=\frac{E}{L(\rho)}=1-(1-q) p\left(R-\frac{B}{\Delta p}\right) .
$$

\footnotetext{
${ }^{14}$ This generalizes the constant $v$ introduced in Section 3 in the case of a single bank. In what follows, $v$ is replaced by $V^{\prime}(\bar{L})$, the marginal value of letting any given bank continue at $t=1 / 2$.
} 
Proof of Proposition 2: Given that there is a separate budget constraint for each $\rho$ (condition (4)), we can solve for $L(\rho)$ and maximize w.r.t. $x$ the following quantity:

$$
U(x, \rho)=\frac{(1-q+q x)\left(p R+V^{\prime}(\bar{L})\right)-q x \rho-1}{1-(1-q+q x) p\left(R-\frac{B}{\Delta p}\right)+q x \rho} .
$$

( $E$ has been omitted because it only appears multiplicatively and therefore does not influence the optimal value of $x(\rho))$. The expression of $U$ can be simplified as follows:

$$
\begin{aligned}
U(x, p) & =-1+\frac{(1-q+q x)\left(V^{\prime}(\bar{L})+\frac{p B}{\Delta p}\right)}{1+q x \rho-(1-q+q x) p\left(R-\frac{B}{\Delta p}\right)}, \\
& =-1+\frac{V^{\prime}(\bar{L})+\frac{p B}{\Delta p}}{\frac{1+q x \rho}{1-q+q x}-p\left(R-\frac{B}{\Delta p}\right)} .
\end{aligned}
$$

For a given $\rho$, this expression is monotonic in $x$ : increasing if $\rho<\frac{1}{1-q}$, decreasing if $\rho>\frac{1}{1-q}$. Thus the optimal regulatory contract involves:

$$
\left\{\begin{array}{rlrl}
x(\rho)=1 & \text { if } & & \rho \leq \frac{1}{1-q} \equiv \rho^{*} \\
=0 & \text { if } & \rho>\rho^{*} .
\end{array}\right.
$$

The corresponding capital ratios are deduced from constraint (4):

$$
k(\rho) \equiv \frac{E}{L(\rho)}=1-\{1-q+q x(\rho)\} p\left(R-\frac{B}{\Delta p}\right)+q \rho x(\rho),
$$

by replacing $x(\rho)$ by its optimal value found above.

Proposition 2 adopts a normative view-point, i.e. it characterizes the optimal closure rule for banks in the presence of macroeconomic shocks. We now adopt a positive view-point 
and compare the optimal closure rule with the effective closure rules implied by two institutional arrangements: pure private contracting between the banks and the DIF on the one hand, and pure public supervision on the other hand.

Proposition 3: A purely private organization of the banking sector leads to too many closures in the event of a recession: indeed, a bank is closed whenever $\rho \leq \rho_{0}=p\left(R-\frac{B}{\Delta p}\right)<\rho^{*}$.

Proof: In the absence of a public intervention, the only way in which a bank can obtain liquidity at the interim date $t=1 / 2$ is by borrowing from other banks (or issuing new CDs). The maximum amount of cash that can be raised in the way is equal to the collateral value of the bank's assets, i.e. the maximal expected payment that can be obtained from bankers while preserving incentive compatibility, i.e.:

$$
\rho_{0} L \equiv p\left(R-\frac{B}{\Delta p}\right) L
$$

Assumption A2 states that $\rho_{0}<1$, which implies that $\rho_{0}<\rho^{*}=\frac{1}{1-q}$. Therefore all the banks with an intermediate exposure to macro-shocks $(\rho \in] \rho_{0}, \rho^{*}[)$ should be allowed to continue, but would be closed in the absence of a public intervention.

Proposition 3 shows the need for the Central Bank acting as a Lender of Last Resort: by providing liquidity assistance to the banks characterized by $\rho \in] \rho_{0}, \rho^{*}[$, the Central Bank improves upon the purely private organization discussed in Proposition 3. However there is also a problem with public intervention. Indeed, once a bank has granted a certain volume of loans, its social continuation value is positive as long as $\rho<p R+V^{\prime}(\bar{L}) \equiv \rho_{1}$, which is larger than $\rho^{*}=\frac{1}{1-q}$ by Assumption 3. If the bank authorities are subject to political pressure, it will be impossible for them to limit liquidity assistance to the banks such that $\rho \leq \rho^{*}$, since it 
is ex-post optimal to let also all the banks such that $\rho \in] \rho^{*}, \rho_{1}[$ continue. Not only this implies too few closures (regulatory forbearance) but also overinvestment at $t=0$, since bankers anticipate this forbearance. This is explained in the next proposition.

Proposition 4: Prudential regulation by a public authority leads to forbearance: all banks such that $\rho \leq \rho_{1}$ receive liquidity support in case of a recession. In this case, the only thing regulatory authorities can do is imposing on these banks a flat capital ratio: ${ }^{15}$

$$
k_{0}=1-(1-q) p\left(R-\frac{B}{\Delta p}\right)
$$

Comparing with the optimal contract characterized in Proposition 2, we see that this leads to overinvestment by these banks, who thus exploit this anticipated regulatory forbearance.

Proof of Proposition 4: We have already seen that it is ex-post optimal for the government to provide liquidity assistance to all banks such that $\rho \leq \rho_{1}=p R+V^{\prime}(\bar{L})$ (positive social continuation value). When $\rho<\rho_{0}$ (solvent banks) this liquidity support is fully collateralized and the central bank does not lose any money. However, when $\left.\rho \in] \rho_{0}, \rho_{1}\right]$, the central bank loses $\left(\rho-\rho_{0}\right) L$ in expectation, but seizes maximum income $\left(R-\frac{B}{\Delta p}\right) L=D$ in case of success. From the DIF point of view the cost of deposit insurance becomes:

$$
P=[(1-q)(1-p)+q] D
$$

The associated capital ratio is

$$
k_{0}=\frac{E}{L}=1+\frac{P-D}{L}=1-(1-q) p\left(R-\frac{B}{\Delta p}\right)
$$

\footnotetext{
${ }^{15}$ Banks such that $\rho<\rho_{0}$ are subject to the same capital ratio as in Proposition 2.
} 
It is smaller than the efficient capital ratio characterized in Proposition 2:

$$
k_{0}<k_{1}(\rho)=1-p\left(R-\frac{B}{\Delta p}\right)+q \rho
$$

This is because $\rho>\rho_{0}=p\left(R-\frac{B}{\Delta p}\right)$. Thus there is overinvestment. Finally, notice that from an ex-ante view point, the marginal social value of loans made by a bank such that $\left.\rho \in] \rho_{0}, \rho_{1}\right]$ is equal to $\left(\rho_{1}-\rho\right)$, which is non negative. This means that it would be inefficient ex-ante to restrict further the volume of credit granted by such banks. Thus the government cannot compensate its lack of commitment power by an increase of capital ratios.

We see this as the fundamental problem faced by prudential supervision: public intervention is needed ${ }^{16}$ in order to avoid too many bank closures, but since governments are subject to commitment problems, public supervision alone leads to too few bank closures and overinvestment. By analogy with Dewatripont and Maskin (1995), we call this a Soft Budget Constraint (SBC) phenomenon. ${ }^{17}$

This problem is summarized by the diagram Figure 3.

\section{[FIGURE 3 ABOUT HERE]}

We discuss in Section 6 a possible organization of banking supervision that could solve this problem. For the moment, we see how introducing market discipline by private investors modifies the picture.

\footnotetext{
${ }^{16}$ Holmström and Tirole (1998) show that, when $\rho$ corresponds to a diversifiable shock, private arrangements between firms and banks (namely private lines of credit) can be enough to implement the (second best) optimum. However when there are macro-shocks, public provision of liquidity is needed.

${ }^{17}$ Notice however that the mechanism that underlies the SBC in Dewatripont and Maskin (1995) is different.
} 


\section{5- IS MARKET DISCIPLINE USEFUL?}

Proponents of market discipline for banks have argued that private investors might have to play a part complementary to public supervisors in the monitoring of commercial banks. In order to discuss the potential monitoring role of private investors, we now introduce an external monitor, who can reduce the unit private benefit of commercial bankers from $B$ to $b<B$ by exerting a monitoring activity of unit $\operatorname{cost} \gamma$. The regulation contract has to stipulate the amount $D_{M}$ that the external monitor is required to invest at $t=0$ (interpreted as subordinated debt) and the repayment $R_{M} L$ he receives in case of success.

The optimal regulation contract for a bank with a macro-exposure $\rho$ is thus obtained by maximizing

$$
W(\rho)=L\left\{(1-q) \rho+q x\left(\rho_{1}-\rho\right)-1-\gamma\right\}
$$

The policy variables are $D \geq 0, L \geq 0, D_{M} \geq 0, R_{M} \geq 0$ and $x \in[0,1]$. They have to satisfy the following constraints:

$$
\begin{gathered}
L[1+q x \rho]-E-D_{M} \leq(1-q+q x) p D \\
\left\{(1-q+q x) p R_{M}-\gamma\right\} L \geq D_{M} \\
R_{M} \geq \frac{\gamma}{\Delta p} \\
\left(R-R_{M}\right) L-D \geq \frac{b L}{\Delta p},
\end{gathered}
$$

where as before $\rho_{1}=p R+V^{\prime}(\bar{L})$.

The objective function of this program is the net social surplus $W(\rho)$ produced by the bank, modified to take into account the cost of monitoring $\gamma L$. Condition (10) is the breakeven constraint for the DIF, modified to take into account the amount $D_{M}$ brought by market investors. Condition (11) is the participation constraint of these market investors. 
Conditions (12) and (13) are respectively the incentive compatibility constraint of market investors and that of the banker.

Again all the constraints bind at the optimum. Thus, $R_{M}=\frac{\gamma}{\Delta p}, D=\left(R-\frac{\gamma+b}{\Delta p}\right) L$, and $D_{M}=\left[(1-q+q x) p \frac{\gamma}{\Delta p}-\gamma\right] L$. Plugging this into the budget constraint (10), we see that the problem reduces to:

$$
\left\{\begin{array}{l}
\max L\left\{(1-q) \rho_{1}+q x\left(\rho_{1}-\rho\right)-1-\gamma\right\} \\
\text { under the constraint } \\
L\left\{1-(1-q+q x) p\left(R-\frac{b}{\Delta p}\right)+q \rho x+\gamma\right\} \leq E
\end{array}\right.
$$

The solution of this program is given in the next proposition.

Proposition 5: The presence of external monitors increases the optimal closure threshold:

$$
\rho^{*}(\gamma)=\frac{1+\gamma}{1-q}>\rho^{*}
$$

In the absence of commitment power by the government, the effective closure threshold remains unchanged at $\rho_{1}$. Capital requirements are then reduced, due to the decrease in bank moral hazard, but the impact on social surplus is ambiguous.

Proof of Proposition 5: Using the same reasoning as in the proof of Proposition 2, the optimal $x(\rho)$ can be obtained by maximizing the expression:

$$
U_{1}(x, \rho)=\frac{(1-q) \rho_{1}+q x\left(\rho_{1}-\rho\right)-1-\gamma}{1-(1-q+q x) p\left(R-\frac{b}{\Delta p}\right)+q x \rho-\gamma},
$$

which can be simplified into: 


$$
U_{1}(x, \rho)=-1+\frac{V^{\prime}(\bar{L})+\frac{p b}{\Delta p}}{\frac{1+q x \rho+\gamma}{1-q+q x}-p\left(R-\frac{b}{\Delta p}\right)} .
$$

For a given $\rho$, this expression is monotonic in $x$ : increasing if $\rho<\frac{1+\gamma}{1-q}$, decreasing if $\rho>\frac{1+\gamma}{1-q}$. Thus the optimal closure threshold is $\rho^{*}(\gamma)=\frac{1+\gamma}{1-q}$. However, if the government cannot commit, the effective closure threshold is still $\rho_{1}=p R+V^{\prime}(\bar{L})$. The capital requirement becomes:

$$
k_{0}^{\prime}=1-(1-q) p\left(R-\frac{b}{\Delta p}\right)<k_{0} \text {. }
$$

It is thus reduced by market discipline. However, since market discipline is costly, the overall impact on social welfare is ambiguous.

The impact of market discipline is summarized in the Figure 4.

\section{[FIGURE 4 ABOUT HERE]}

Therefore if we compare it to the optimal contract with commitment, the use of an external monitor is not necessarily beneficial. More importantly, market discipline does not completely solve the commitment problem, except if the external monitor cannot exert pressure on politicians. Suppose indeed that the market debt $D_{M}$ is held by foreign investors, as suggested in Calomiris (1999), and suppose that these foreign investors cannot lobby ${ }^{18}$ the national regulator. In this case, the commitment problem of the latter will be reduced, since the ex post socially optimal continuation threshold will be reduced to $\rho_{1}^{\prime}=\rho_{1}-p R_{F}$, where $R_{F}$ is the promised repayment to foreign investors in case of success. An adequate choice of 
$R_{F}$ will give $\rho_{1}^{\prime}=\rho^{*}(\gamma)$. Therefore, the main interest of using foreign investors as external monitors of national banks is to solve the commitment problem of the regulator. By pledging future income to outsiders (who cannot lobby political authorities) the regulator becomes tougher. However, the expected surplus is not necessarily increased, especially if foreign investors are characterized by high monitoring costs $\gamma$ and low monitoring effectiveness $B-b$.

An alternative solution to the commitment problem exists, which does not have all these drawbacks: requiring independency and accountability of banking supervisors, like has been done for monetary policy. We now conclude by examining how this reform could be organized, taking into account the need for a lender of last resort.

\section{6- POLICY RECOMMENDATIONS FOR MACRO-PRUDENTIAL REGULATION}

We conclude this paper by offering some reflections on the ways in which the optimal contract characterized in Section 4 can be implemented by an adequate design of the supervisory-regulatory system. As we saw in Section 4, two crucial elements are needed:

- Intervention of the central bank as a lender of last resort for providing liquidity assistance, in case of a recession, to the banks characterized by $\rho \leq \rho^{*}$.

- Preventing extension of this liquidity assistance to the banks characterized by $\rho^{*}<\rho \leq \rho_{1}$, for which ex post continuation value is positive (from a social point of view) but bailing them out would be welfare decreasing from an ex-ante perspective.

\footnotetext{
${ }^{18}$ This is probably questionable, given the internationalization of capital markets and the huge size of the major investors, who are typically multinational firms.
} 
We claim that these two elements can only be reconciled if the central bank is made independent from political authorities, like has been done for monetary policy. To ensure accountability of the central bank in its functions of a lender of last resort, a precise agenda has to be defined ex ante, namely providing liquidity assistance to a subset of banks (those for which $\rho \leq \rho^{*}$ ) that would be backed by the supervisors (or the DIF). To ensure that the DIF selects properly the banks that can be assisted, we require that the liquidity loans granted by the central bank (acting as a lender of last resort) would be backed by the DIF. In other words, those loans would be insured by the DIF: the central bank would be completely protected against credit risk and no tax payer money would be involved. The next proposition summarizes the proposed organization of the regulatory system.

Proposition 6: The optimal contract (characterized in Proposition 2) can be implemented by the following organization of the regulatory system:

- For each commercial bank, the supervisory authorities evaluate $\rho$, the bank's exposure to macroeconomic shocks, which determines the treatment of the bank by regulators.

- Banks with a small exposure, $\left(\rho \leq \rho^{*}\right)$ are backed by the DIF and, in case of a macro shock, receive liquidity assistance by the Central Bank. They face a capital adequacy requirement $k(\rho)$ and a deposit insurance premium $P(\rho)$ that increase with $\rho$ :

$$
\begin{aligned}
& k(\rho)=1-p\left(R-\frac{B}{\Delta p}\right)+q \rho \\
& P(\rho)=D\left(1-p+p q \frac{\rho}{\rho_{0}}\right) .
\end{aligned}
$$

- Banks with a large exposure to macro-shocks $\left(\rho>\rho^{*}\right)$ are not backed by the DIF: they don't receive liquidity assistance by the Central Bank. They 
face a capital requirement $k_{0}$ and a deposit insurance premium $P_{0}$ that do not depend on $\rho$ :

$$
\begin{aligned}
& k_{0}=1-(1-q) p\left(R-\frac{B}{\Delta p}\right) \\
& P_{0}=D(1-p+p q) .
\end{aligned}
$$

- The lender of last resort activities of the central bank are made independent from political powers: the central bank exclusively provides liquidity assistance to the banks that are backed by supervisory authorities. Central bank loans are fully insured by the DIF.

This organization can be summarized by the diagram Figure 5 .

[FIGURE 5 ABOUT HERE] 


\section{REFERENCES}

D'Amato, L., E. Grubisik and A. Powell, 1998, "Contagion, Banks Fundamentals or Macroeconomic Shocks", Bank of Argentina discussion paper.

Basel Committee on Banking Supervision, 1988, "International Convergence of Capital Measurement and Capital Standards", paper issued by the Basel Committee on Banking Supervision (BCBS), Basel, Switzerland.

Besanko, D., Kanatas, G., 1996, The Regulation of Bank Capital: Do Capital Standards Promote Bank Safety?. Journal of Financial Intermediation 5(4), 160-183.

Blum, J., 1999, Do Capital Adequacy Requirements Reduce Risk in Banking?. Journal of Banking and Finance 23(5), 755-771.

Blum, J., Hellwig, M., 1995, The Macroeconomic Implications of Capital Adequacy Requirements for Banks. European Economic Review, 39, 739-749.

Boot, A. and S. Greenbaum, 1993, Bank Regulation, Reputation and Rents: Theory and Policy Implications: in C. Mayer and X. Vives (Eds), Capital Markets and Financial Intermediation, Cambridge University Press.

Calomiris, C., 1998, Blueprints for a New Global Financial Architecture, www.house.gov/jec/imf/blueprint.htm.

Calomiris, C., 1999, Building and Incentive-Compatible Safety Net. Journal of Banking and Finance, 23, 1499-1519.

Caminal, R., Matutes, C., 2002, Market Power and Banking Failures. International Journal of Industrial Organization, 20 (9), 1341-1361. 
Cook D.O., Spellman, L.J., 1996, Firm and Guarantor Risk, Risk Contagion and the Interfirm Spread Among Insured Deposits. Journal of Financial and Quantitative Analysis, 31(2), $265-281$.

Cull, R., 1998, The Effect of Deposit Insurance on Financial Depth: A Cross-Country Analysis. The World Bank, working paper series 1875.

Décamps, J.P., J.C. Rochet and B. Roger, 2004, The 3 Pillars of Basel II: Optimizing the Mix. forthcoming, Journal of Financial Intermediation.

Degryse, H., Van Cayseele, P., 2000, Relationship Lending within a Bank-Based System: Evidence from European Small Business Date. Journal of Financial Intermediation, 9(1), 90-109.

Demirgüc-Kunt, A., Detragiache, E., 1997, The Determinants of Banking Crises: Evidence form Developed and Developing Countries. Policy Research Working Paper 1828, The World Bank, Washington D.C., USA.

Dewatripont, M., Maskin, E., 1995, Credit and Efficiency in Centralized and Decentralized Economies. Review of Economic Studies, 62, 541-555.

Dewatripont, M. and J. Tirole, 1994, The Prudential Regulation of Banks, The MIT Press, Cambridge Mass. USA.

Diamond, D., 1984, Financial Intermediation and Delegated Monitoring. Review of Economic Studies, 51, 393-414.

Ellis D., Flannery, M., 1992. Does the Debt Market Assess Large Banks' Risk?. Journal of Monetary Economics, 481-502.

Evanoff, D., 1993, Preferred Sources of Market Discipline. Yale Journal of Regulation, 10, $347-367$.

Flannery, M.J., 1998, Using Market Information in Prudential Bank Supervision: A review of the U.S. Empirical Evidence. Journal of Money Credit and Banking, 30, 273-305. 
Flannery, M.J., Sorescu, S.M., 1996, Evidence of Bank Market Discipline in Subordinated Debenture Yields: 1983-1992. Journal of Finance, 51(4), 1347-1377.

Freixas, X., B. Parigi and J.C. Rochet, 2000, Systemic Risk, Interbank Relations and Liquidity Provision by the Central Bank. Journal of Money, Credit and Banking, 3(2), 611-638.

Furfine, C., 2000, Evidence on the Response of US Banks to Changes Capital Requirements. BIS Working Paper 88, Basel, Switzerland.

Furlong, F., Keeley, M., 1989, Bank Capital Regulation and Risk Taking: A Note. Journal of Banking and Finance, 49-71.

Gorton, G., Santomero, A., 1990, Market Discipline and Bank Subordinated Debt. Journal of Money, Credit and Banking, 22(1), 119-128.

Goodfriend, M., Lacker, J., 1999, Limited Commitment and Central Bank Lending. Federal Reserve Bank of Richmond, Working Paper 99-2, Richmond Va, USA.

Hannan, T.H., Hanweck, G.A., 1988, Bank Insolvency Risk and the Market for Large Certificates of Deposit. Journal of Money, Credit and Banking, 20, 203-211.

Hellman, T.F., K.C. Murdock and J.E. Stiglitz, 2000, Liberalization Moral Hazard in Banking, and Prudential Regulation: Are Capital Requirements Enough?. American Economic Review, 90(1), 147-165.

Holmström, B., Tirole, J., 1997, Financial Intermediation, Loanable Funds and the Real Sector. Quarterly Journal of Economics, 112, 663-691.

Holmström, B., Tirole, J., 1998, Private and Public Supply of Liquidity. Journal of Political Economy, 106, 1-40.

Jones, D., 2000, Emerging Problems with the Basel Capital Accord: Regulatory Capital Arbitrage and Related Issues. Journal of Banking and Finance, 21(4), 491-507. 
Kim, D., Santomero, A., 1988, Risk in Banking and Capital Regulation. Journal of Finance, $43,1219-1233$.

Lindgren, C., G. Garcia and M. Saal, 1996, Bank Soundness and Macroeconomic Policy. Washington DC.

Martinez Peria, M.S., Schmukler, S.L., 2001, Do Depositors Punish Banks for "Bad" Behavior? Market Discipline, Deposit Insurance and Banking Crises. Journal of Finance, 56(3), 1029-1051.

Milne, A., Whalley, E., 1998, Bank Capital Regulation and Incentives for Risk Taking. discussion paper, City University Business School, London, U.K.

Park, S., Peristiani, S., 1998, Market Discipline by Thrift Depositors. Journal of Money Credit and Banking, 26, 439-459.

Rochet, J.C., 1992, Capital Requirements and the Behaviour of Commercial Banks. European Economic Review, 36, 1137-1178.

Rochet, J.C., Tirole, J., 1996, Interbank Lending and Systemic Risk. Journal of Money, Credit and Banking, 28(4), 733-762.

Sharpe, S., 1990, Asymmetric Information, Bank Lending and Implicit Contracts: A Stylized Model of Customer Relationships. Journal of Finance, 45, 1069-85.

Sironi, A., 2000, An Analysis of European Bank SND Issues and its Implications for the Design of a Mandatory Subordinated Debt Policy. Journal of Financial Services Research, 19, 233-266.

Solow, R., 1982, On the Lender of Last Resort. In: Kindleberger, C.P. , Laffarge, J.P. (Eds), Financial Crises: Theory, History and Policy, Cambridge University Press, 237-248.

Wall, L.D., 1989, A Plan for Reducing Future Deposit Insurance Losses: Puttable Subordinated Debt. Economic Review (July/August) 2-17. 
Figure 1: The time line of the model.

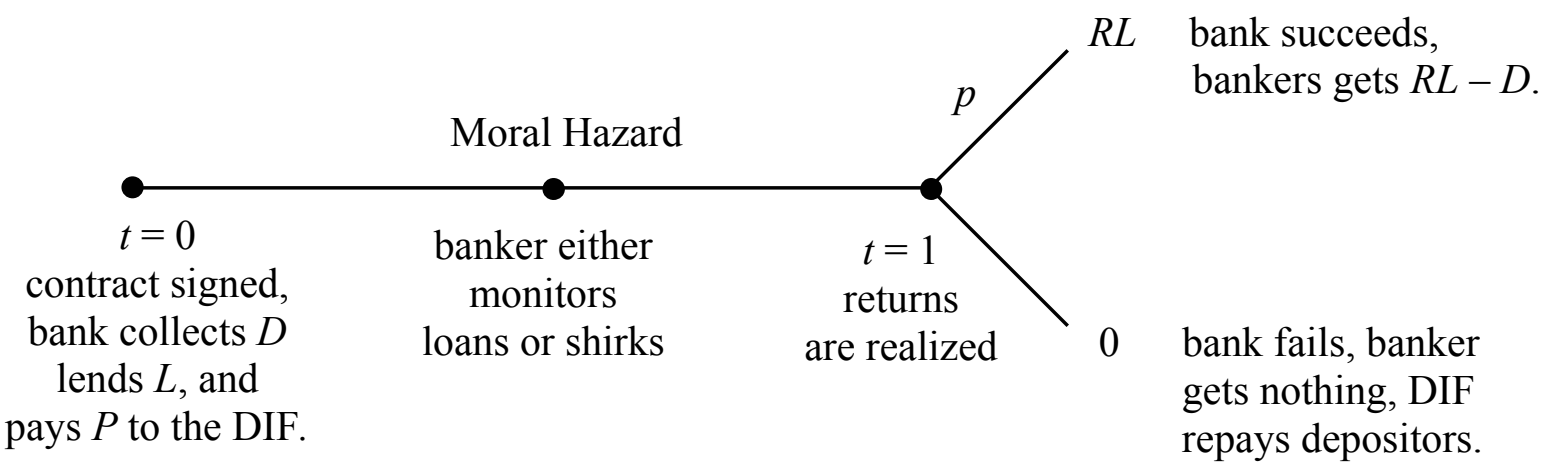

Figure 2: The time line in the presence of macro-shocks.

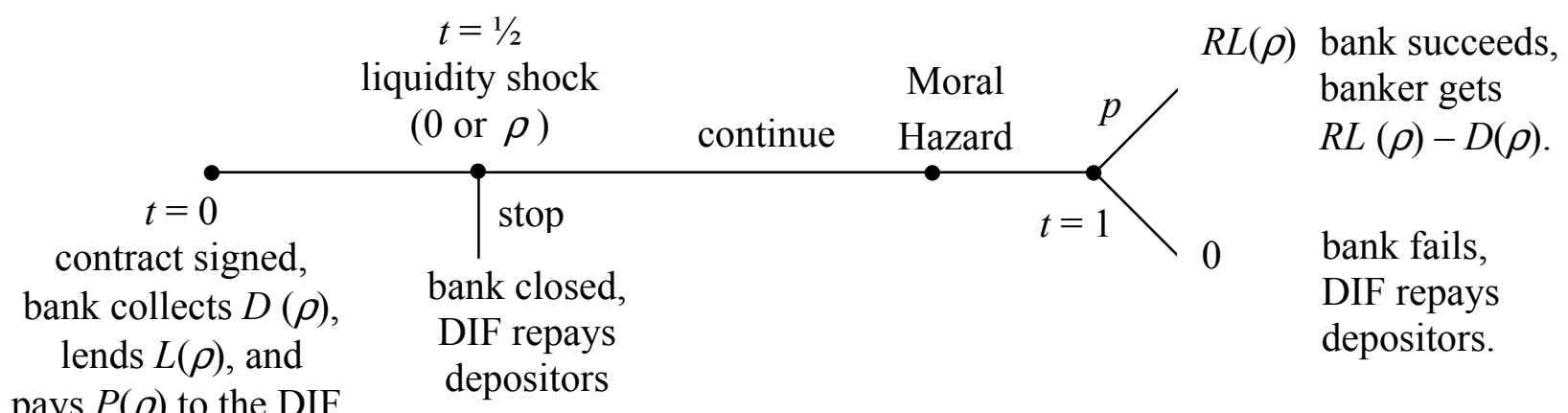


Figure 3: The fundamental problem faced by prudential supervision.

\begin{tabular}{c|c|c|c}
$\begin{array}{c}\text { Solvent } \\
\text { Banks }\end{array}$ & $\begin{array}{c}\text { Need for a } \\
\text { lender of } \\
\text { last resort }\end{array}$ & $\begin{array}{c}\text { Regulatory } \\
\text { forbearance }\end{array}$ & $\begin{array}{c}\text { Banks that are closed } \\
\text { if a macro-shock occurs }\end{array}$ \\
\hline & $\rho_{0}$ & $\rho^{*}$ & $\rho_{1}$
\end{tabular}

Figure 4: The impact of market discipline

( $\rho^{*}$ is increased to $\rho^{*}(\lambda)$ but $\rho_{1}$ is unchanged)

\begin{tabular}{c|c|c|c}
$\begin{array}{c}\text { Solvent } \\
\text { Banks }\end{array}$ & $\begin{array}{c}\text { Need for a } \\
\text { lender of } \\
\text { last resort }\end{array}$ & $\begin{array}{c}\text { Regulatory } \\
\text { forbearance }\end{array}$ & $\begin{array}{c}\text { Banks that are closed } \\
\text { if a macro-shock occurs }\end{array}$ \\
\hline & $\rho_{0}$ & $\rho^{*} \rho^{*}(\gamma)$ & $\rho_{1}$
\end{tabular}


Figure 5: The optimal management of bank closures.

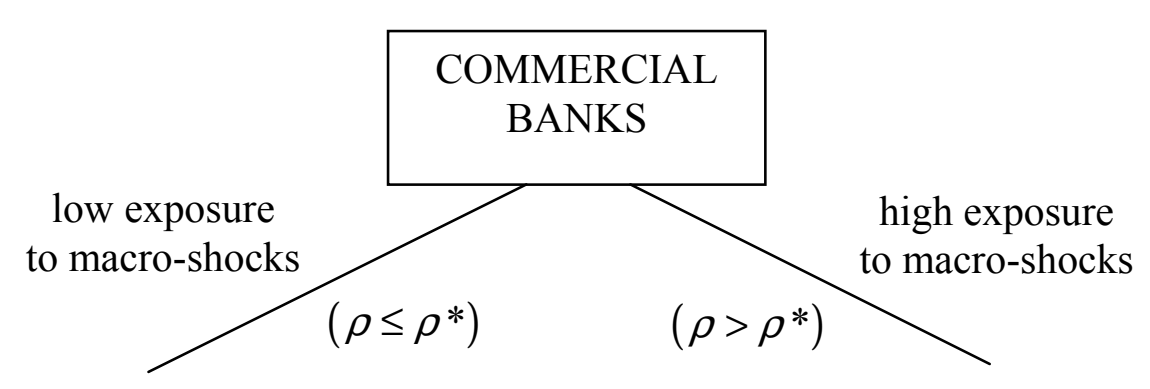

- Have access to Emergency Liquidity Assistance by the Central Bank.

- Pay a deposit insurance premium that increases with $\rho$ :

$$
P(\rho)=D\left(1-p+p q \frac{\rho}{\rho_{0}}\right) .
$$

- Are subject to a capital requirement that increases with $\rho$ :

$$
k_{1}(\rho)=1-\rho_{0}+q \rho \text {. }
$$

- Have no access to Emergency Liquidity Assitance by the Central Bank.

- Pay a flat deposit insurance

$$
P_{0}=D(1-p+p q) \text {. }
$$

- Are subject to a flat capital requirement

$$
k_{0}=1-(1-q) \rho_{0} \text {. }
$$

